\title{
Contribution to diagnostics/prognostics of tuberculosis in children. I. New methods of assaying zinc and simultaneously copper and zinc in diluted sera by flame atomic-absorption spectrometry
}

\author{
SVJETLANA LUTEROTTI ${ }^{1}$ \\ TONČICA VUKMAN KORDIĆ ${ }^{2}$ \\ SLAVICA DODIG ${ }^{3}$ \\ ${ }^{1}$ Faculty of Pharmacy and \\ Biochemistry, University of Zagreb \\ HR-10000 Zagreb, Croatia \\ ${ }^{2}$ Agency for Medicinal Products \\ and Medical Devices \\ HR-10000 Zagreb, Croatia \\ ${ }^{3}$ Srebrnjak Children's Hospital \\ HR-10000 Zagreb, Croatia
}

Accepted June 15, 2015

\begin{abstract}
In an attempt to provide a reliable status of metal ions in children, new methods of analysis of children's sera are proposed. New flame atomic-absorption spectrometric (FAAS) methods are simple, cost- and time-effective and, above all, labor-, reagent- and sample-saving. Two methods were suggested: method A for simultaneous determination of $\mathrm{Cu}$ and $\mathrm{Zn}$ from 5-fold diluted sera, and method B, for assaying zinc alone in 10-fold diluted samples. Both methods are based on a single-step sample pretreatment (deproteinization with $3 \mathrm{~mol} \mathrm{dm}{ }^{-3} \mathrm{HCl}$ ). Method A uses a singlestep calibration with a mixed standard. The main advantage of method B is an additional reduction in sample consumption. Both methods were fully validated against reference methods. Accuracy, sensitivity and precision have proven them to be comparable to the reference methods in terms of analytical performance, and applicable to analyses of children's sera.
\end{abstract}

Keywords: copper, zinc, flame atomic-absorption spectrometry, single-step analysis, children's serum

In many organisms, including humans, concentrations of metal ions are good indicators of the sufficiency or deficiency of an organism's metal ion supply, or a pathological state. Several atomic absorption spectrometric approaches have been implemented, flame atomic-absorption spectrometry (FAAS) being one of the most successful (1). When analyses of clinical specimens are undertaken, analytical instrumentation is usually selected with regard to the analyte(s), their concentration and the matrix (or matrices). Inductively coupled plasma - mass spectrometry is the logical choice when biomonitoring for a panel of trace elements at background levels is the analytical task (2). However, flame or graphite furnace atomic absorption (FAAS/GFAAS) or emission spectrometry such as inductively coupled plasma - optical emission spectrometry are usually applied to the analyses of metal ions in clinical samples. All these techniques require elaborate and costly pretreatments of the samples.

\footnotetext{
*Correspondence; e-mail: svjetlana.luterotti@pharma.hr; svjetlana.luterotti@gmail.com
} 
Weinstock and Uhlemann (3) proposed automated injection of microliter samples into FAAS for determination of copper in untreated sera. Also, Makino and Takahara (4) proposed micromethods for determination of metal ions in children by FAAS; for $\mathrm{Cu}$ and $\mathrm{Zn}$, they reported simple dilution with water. Terres-Martos et al. (5) proposed FAAS for determination of copper in human serum mineralized with an $\mathrm{HNO}_{3} / \mathrm{HClO}_{4}(4: 1)$ mixture and heated to $120{ }^{\circ} \mathrm{C}$ in a mineralization block, while Lopes et al. (6) described a fully automated flow system to accomplish sequential determination of copper in serum and urine by FAAS. Salmela and Vuori (7) proposed a FAAS method for $\mathrm{Cu}$ and $\mathrm{Zn}$ in serum diluted with water, adoptable to pediatric research. Even nowadays, reference methods suggest assaying of sera for copper and zinc after simple dilution with water (8).

Here, we report on the continuation of our research to develop new reliable analytical procedures for quantitation of metal ions in human sera by FAAS $(9,10)$. We are suggesting new methods for simultaneous determination of $\mathrm{Cu}$ and $\mathrm{Zn}$ in serum and of zinc alone, based on single-step pretreatment of the sample. The methods are intended for use in diagnostic/prognostic screening of pediatric tuberculosis.

\section{EXPERIMENTAL}

\section{Materials}

Reagents. - Ultrapure water (electrolytic conductivity $0.055 \mu \mathrm{S} \mathrm{cm}^{-1}$ ) was used throughout. Hydrochloric acid 35 \% (Lach-Ner, Czech Republic), glycerol (Gram-mol, Croatia), $\mathrm{NaHCO}_{3}$ (Kemika, Croatia), $\mathrm{Na}_{2} \mathrm{HPO}_{4} \times 2 \mathrm{H}_{2} \mathrm{O}$ (Merck, Germany), $\mathrm{KCl}$ (Lach-Ner), $\mathrm{MgCl}_{2} \times$ $6 \mathrm{H}_{2} \mathrm{O}$ (Kemika), $\mathrm{CaCl}_{2} \times 2 \mathrm{H}_{2} \mathrm{O}$ (Merck Alkaloid, Macedonia), $\mathrm{NaCl}$ (Zorka, Serbia) and $\mathrm{HNO}_{3} 65 \%$ (Kemika) were all of pro analysi grade.

Human albumin $20 \%$ and human intravenous immunoglobulin $5 \%$ were both from the Institute of Immunology (Zagreb, Croatia).

Serum samples. - All experiments were approved by the Ethical Committees of the Srebrnjak Children's Hospital, Zagreb, Croatia, and Faculty of Pharmacy and Biochemistry, University of Zagreb, Zagreb, Croatia. To establish new methods, the pool of remnant children's sera was used. All sera samples were obtained from the Children's Hospital Srebrnjak, Zagreb, Croatia, in 2006 and 2007 , and were stored at $-18^{\circ} \mathrm{C}$. Before analysis, the serum sample was thawed overnight and mixed for $10 \mathrm{~min}$.

$\mathrm{HCl}$-acidified serum pool was prepared by adding $3 \mathrm{~mol} \mathrm{dm}{ }^{-3} \mathrm{HCl}$ into the serum pool to a final dilution ratio 1:5 (AS/5) or 1:10 (AS/10).

Synthetic serum (real blank). - Synthetic serum was prepared so as to mimic human serum (ionic strength approximately $145 \mathrm{mmol} \mathrm{L}^{-1}$ ): human albumin and human immunoglobulin 5 and $2 \%, \mathrm{Na}^{+}, \mathrm{Cl}^{-}, \mathrm{HCO}_{3}^{-}, \mathrm{HPO}_{4}{ }^{2-}, \mathrm{K}^{+}, \mathrm{Mg}^{2+}, \mathrm{Ca}^{2+}\left(151,91,25,1,4,1,2.5 \mathrm{mmol} \mathrm{L}{ }^{-1}\right.$, resp.). Synthetic serum was stored at $+4{ }^{\circ} \mathrm{C}$.

$\mathrm{HCl}$-acidified synthetic serum was prepared by adding $3 \mathrm{~mol} \mathrm{dm}^{-3} \mathrm{HCl}$ into synthetic serum to a final 1:5 (ASM/5) or 1:10 (ASM/10) dilution ratio.

Standard solutions. - Stock standard solutions were $1026.81 \mu \mathrm{g} \mathrm{mL}-1 \mathrm{Cu}$ and $1061.77 \mu \mathrm{g} \mathrm{mL}^{-1}$ $\mathrm{Zn}$. Copper stock solution was prepared by dissolving $\mathrm{CuCl}_{2} \times 2 \mathrm{H}_{2} \mathrm{O}$ in $0.1 \mathrm{~mol} \mathrm{~L}^{-1} \mathrm{HCl}$; $\mathrm{Zn}$ stock solution was obtained by dissolving elemental zinc in $11.7 \mathrm{~mol} \mathrm{~L}-1 \mathrm{HCl}$. Both stock solutions were standardized complexometrically and diluted to interdilution of $10 \mu \mathrm{g} \mathrm{mL}^{-1}$. 
Calibration standards were prepared fresh daily. Working standard solutions for calibration for both metal ions $(0.2,0.4,0.6,0.8,1.0,1.2,1.6$ and $2.0 \mu \mathrm{g} \mathrm{mL}-1$ metal ion) were obtained from the interdilution and different diluents. For simultaneous determination of $\mathrm{Cu}$ and $\mathrm{Zn}$ (method A), these were $0.6 \mathrm{~mol} \mathrm{~L}^{-1} \mathrm{HCl}, 5 \%$ glycerol, $\mathrm{HCl}$-acidified synthetic serum (ASM/5), and for Zn alone (method B) $0.3 \mathrm{~mol} \mathrm{~L}^{-1} \mathrm{HCl}, 4 \%$ glycerol and HCl-acidified synthetic serum (ASM/10).

Individual standard solutions of $\mathrm{Cu}$ and $\mathrm{Zn}$ and mixed standard solutions $(\mathrm{Cu}+\mathrm{Zn})$ were prepared in $0.6 \mathrm{~mol} \mathrm{~L}^{-1} \mathrm{HCl}$ for simultaneous determination of metal ions.

Calibration standards in ASM/5 $\left(0.6 \mathrm{~mol} \mathrm{~L}^{-1} \mathrm{HCl}\right)$ or ASM/10 $\left(0.3 \mathrm{~mol} \mathrm{~L}^{-1} \mathrm{HCl}\right)$ were prepared from synthetic serum, $3 \mathrm{~mol} \mathrm{~L}^{-1} \mathrm{HCl}$ and water, and interdilutions of metal ions. ASM/5 or ASM/10 with no analyte added served as blank sample.

For standard additions (0.3, 0.5, 0.7, 1.0, 1.5 and $2.0 \mu \mathrm{g} \mathrm{mL} \mathrm{mL}^{-1}$ metal ion), $\mathrm{HCl}$-acidified serum pool was used together with interdilutions of metal ions, $3 \mathrm{~mol} \mathrm{~L}-1 \mathrm{HCl}^{-1}$ and water to obtain systems equaling $\mathrm{AS} / 5$ and $0.6 \mathrm{~mol} \mathrm{~L}^{-1} \mathrm{HCl}$, or $\mathrm{AS} / 10$ and $0.3 \mathrm{~mol} \mathrm{~L}^{-1} \mathrm{HCl}$.

\section{Equipment}

The FAAS instrument used was a PerkinElmer (USA) AAnalyst 800 atomic absorption spectrometer with deuterium background corrector (DBC). Applied instrumental parameters are given in Table I.

A microcentrifuge Eppendorf 5415D (Eppendorf, Germany) was used for centrifugation of samples.

\section{Analytical procedures}

To avoid contamination of samples and standard solutions, both the laboratory glassware and plasticware were soaked in nitric acid 1:1 for $24 \mathrm{~h}$ and then rinsed several times with ultrapure water.

Determination of $\mathrm{Cu}$ in serum by the modified reference method (8). - Sample (serum pool) was diluted 5 -fold with ultrapure water, homogenized and let settle. The supernatant was

Table I. Instrumental parameters

\begin{tabular}{lcc}
\hline Element & $\mathrm{Cu}$ & $\mathrm{Zn}$ \\
\hline Lamp type & HCL $^{\mathrm{a}}$ & $\mathrm{HCL}^{\mathrm{a}}$ \\
Lamp current $(\mathrm{mA})$ & 15 & 15 \\
Wavelength $(\mathrm{nm})$ & 324.8 & 213.9 \\
Slit setting $(\mathrm{nm})$ & 0.7 & 0.7 \\
Fuel/oxidant & acetylene/air \\
Acetylene pressure $(\mathrm{Pa}) /$ flow rate $\left(\mathrm{L} \mathrm{min}^{-1}\right)$ & $9 \times 10^{4} / 2$ \\
Air pressure $\left(\right.$ Pa)/flow rate $\left(\mathrm{L} \mathrm{min}^{-1}\right)$ & \multicolumn{2}{c}{$5.5 \times 10^{5} / 17$} \\
\hline
\end{tabular}

${ }^{a}$ Hollow cathode lamp. 
aspirated directly into the nebulizer system of the instrument. Copper concentration was determined by comparison with standard solutions prepared in $5 \%$ glycerol.

Determination of $\mathrm{Zn}$ in serum by the reference method (8). - Sample (serum pool) was diluted 5-fold with ultrapure water, homogenized and let settle. The supernatant was aspirated directly into the nebulizer system of the instrument. Concentration of zinc was determined by comparison with standard solutions prepared in $5 \%$ glycerol.

Determination of $\mathrm{Zn}$ in serum by the modified reference method (8). - Sample (serum pool) was diluted 10-fold with ultrapure water, homogenized and let settle. The supernatant was aspirated directly into the nebulizer system of the instrument. Zinc concentration was determined against standard solutions prepared in $4 \%$ glycerol.

Optimization of new methods and general procedures. - Optimization was performed by varying experimental parameters (10). Optimum parameters were already reported as: 3 mol L ${ }^{-1} \mathrm{HCl}$ for serum deproteinization, stirring time $5 \mathrm{~min}$, settling/heating time and temperature: $5 \mathrm{~min} / 50^{\circ} \mathrm{C}$, centrifugation time and speed: $10 \mathrm{~min} / 15,000 \mathrm{~g}(10)$.

Measurements of supernatants-aspirates were corrected for blank values.

Method A. New method for simultaneous determination of $\mathrm{Cu}$ and $\mathrm{Zn}$ in serum at a dilution ratio of 1:5. - Deproteinization of the serum sample was performed by adding $3 \mathrm{~mol} \mathrm{~L}^{-1} \mathrm{HCl}$ in a ratio 1:2 and stirring, then diluting with water to a total dilution ratio of 1:5, mixing, heating and centrifuging. Obtained serum samples were 5 -fold diluted, with the final concentration of $\mathrm{HCl}$ of $0.6 \mathrm{~mol} \mathrm{~L}^{-1}$.

Method B. Newly modified assay of Zn in serum at a dilution ratio of 1:10. - Deproteinization was performed by adding $3 \mathrm{~mol} \mathrm{~L}^{-1} \mathrm{HCl}$ in a ratio 1:2 and stirring, then diluted with water to a total dilution ratio of 1:10, mixing, heating and centrifuging. Obtained sera samples were 10 times diluted, with the final concentration of $\mathrm{HCl}$ of $0.3 \mathrm{~mol} \mathrm{~L}^{-1}$.

Data analysis. - Analytical performances were evaluated according to ICH guidelines (11). Calibration sensitivity (CS) was given by the slopes of regression lines. Detection limit $(D L)$ was evaluated according to the relation: $D L=3.3 \times \mathrm{SD}_{\mathrm{i}} / C S\left(\mathrm{SD}_{\mathrm{i}}\right.$ is standard deviation of the calibration line intercept). Precision was given both as repeatability and intermediate precision.

Data obtained for the reference methods and the proposed methods, A and B, including different calibration approaches, were statistically compared on the basis of: (i) calibration sensitivity and (ii) estimated concentration of analyte in the serum pool. Regression line parameters and all concentration estimates were given as mean \pm SD values.

TWOLINE and TWOLINE1 programs were used for the analysis of parallelism between calibration lines. Two-tailed distributions at significance level of 0.05 were applied for both non-parametric tests (Mann-Whitney U-value, Kruskal-Wallis) and $t$ - and F-tests.

\section{RESULTS AND DISCUSSION}

\section{Trueness of new methods}

Method A. Simultaneous determination of copper and zinc in serum. - Trueness and reliability of the method were demonstrated by the results for analyte concentration, calibra- 
S. Luterotti et al:: Contribution to diagnostics/prognostics of tuberculosis in children. I. New methods of assaying zinc and simultaneously copper and zinc in diluted sera by flame atomic-absorption spectrometry, Acta Pharm. 65 (2015) 311-320.

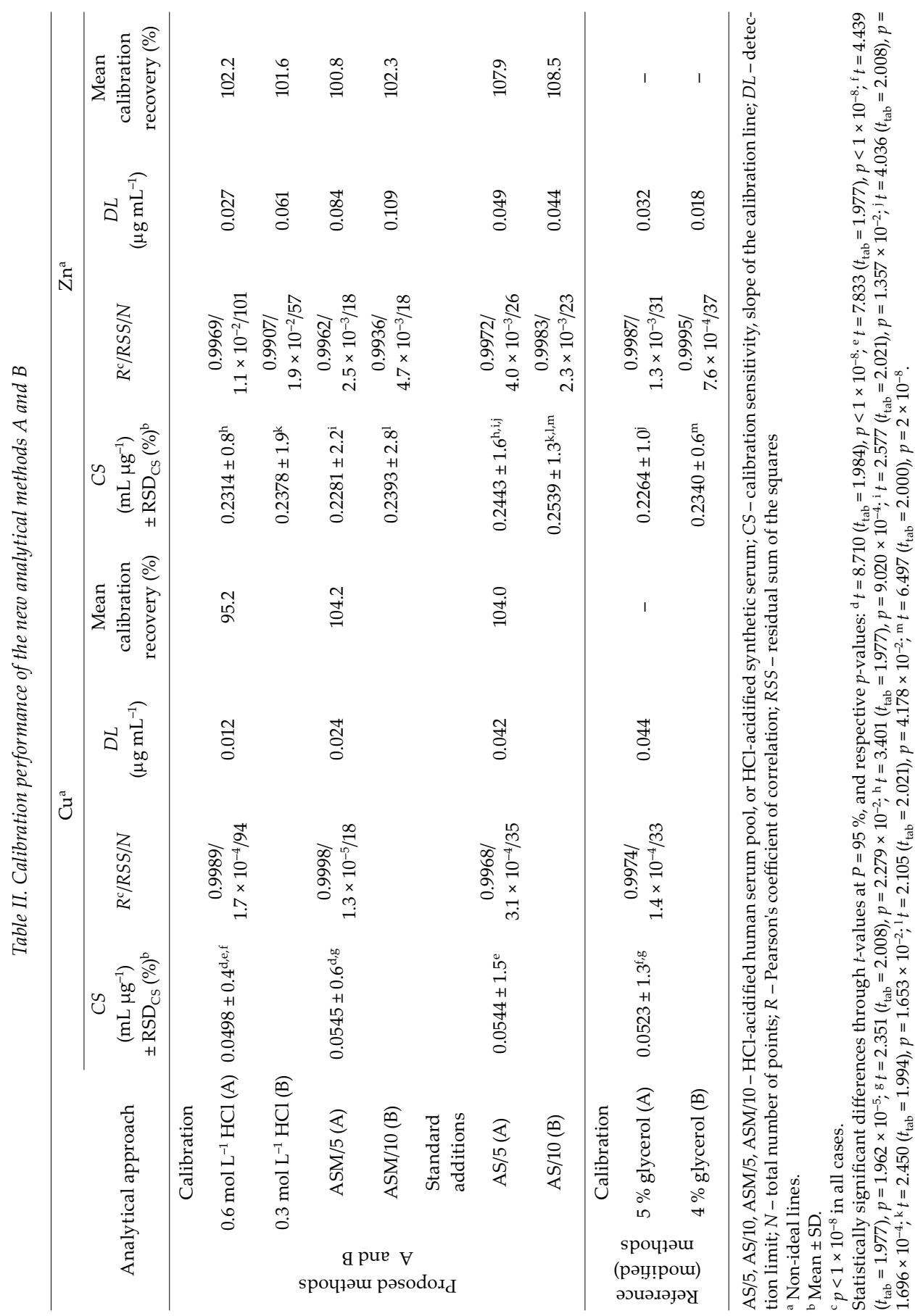


tion sensitivity, detection limit, accuracy and precision. The newly proposed method was statistically compared with the reference methods by various calibration approaches (standard additions in $\mathrm{HCl}$-acidified serum $\mathrm{AS} / 5$, calibration in $\mathrm{HCl}$-acidified synthetic serum $\mathrm{ASM} / 5$, and calibration in $\left.0.6 \mathrm{~mol} \mathrm{~L}^{-1} \mathrm{HCl}\right)$.

Analytical performances evaluated during method optimization are displayed in Tables II-IV.

Separate calibrants versus combined calibrant. - For calibrations in $0.6 \mathrm{~mol} \mathrm{~L}-1 \mathrm{HCl}$, slopes and intercepts of calibration lines obtained for $\mathrm{Cu}$ and $\mathrm{Zn}$ per se and in a mixture were statistically compared. No statistically significant differences were found for either slope or intercept; moreover, $R$ values were $\geq 0.9993$ in all cases (data not shown). Hence, calibration was further executed from a mixed calibrant solution.

Calibration and recovery. - Collective calibration data for both analytes were used to observe the effects on calibration sensitivity (CS, Table II). Calibration range of 0.1-2.0 $\mu \mathrm{g} \mathrm{mL} \mathrm{m}^{-1}$ for both metal ions was investigated. $R-\left(R>0.996, p<1 \times 10^{-8}\right)$ and $R S S$-values $(1.3$ $\times 10^{-5}$ to $1.1 \times 10^{-2}$ ) speak in favor of strong linear correlation in all systems. Imprecision of the calibration line slope was $0.4-1.5 \%$ for $\mathrm{Cu}$ and $0.8-2.2 \%$ for $\mathrm{Zn}$.

Comparable values of calibration sensitivity were obtained by different calibration ap-

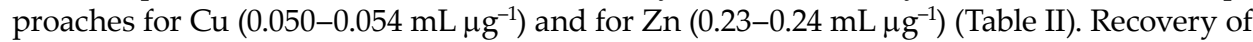
calibration relative to the reference method was 95-104 and 101-108 \%, respectively. However, differences $>4 \%$ were recognized as significant, making the calibration line slope for $\mathrm{Cu}$ in $5 \%$ glycerol significantly different from that in $0.6 \mathrm{~mol} \mathrm{~L}{ }^{-1} \mathrm{HCl}$ and in $\mathrm{ASM} / 5$ but not from standard additions into AS/5, at $P=95 \%$. The latter differed significantly only from calibration in $0.6 \mathrm{~mol} \mathrm{~L}^{-1} \mathrm{HCl}$. As far as zinc is concerned, calibration sensitivity in $5 \%$ glycerol differed significantly from the method of standard additions only.

In the next step, concentrations of both analytes were estimated in pooled sera (Table III). All concentrations lay within reference intervals for copper and zinc in the sera of general child population $(12,13)$.

The results obtained through concentrations and through CS-values differ to some extent. In the case of copper, the concentration estimated from $5 \%$ glycerol did not significantly differ from calibration in $0.6 \mathrm{~mol} \mathrm{~L}^{-1} \mathrm{HCl}$ or standard additions to $\mathrm{HCl}$-acidified serum pool but differed significantly from calibration in $\mathrm{HCl}$-acidified real blank. Zinc concentration estimated by the reference method did not differ significantly from either of the new approaches applied. Here, the bias as high as $\pm 10 \%$ was not recognized as significant. Summing up, we found that calibrations in $5 \%$ glycerol did not differ significantly from either calibration in $0.6 \mathrm{~mol} \mathrm{~L}^{-1} \mathrm{HCl}$ or standard additions, for both metal ions, at $P=95 \%$ (Table III). Respective recoveries of 99 and $90 \%$ for $\mathrm{Cu}$ and 91 and $101 \%$ for $\mathrm{Zn}$ were calculated. This data is in concordance with the recovery requirements in bioanalytics (14). In conclusion, the latter approaches might reliably replace each other and the reference calibration medium as well. For the sake of simplicity, $0.6 \mathrm{~mol} \mathrm{~L}^{-1} \mathrm{HCl}$ was suggested as medium for calibration instead of $5 \%$ glycerol for simultaneous determination of zinc and copper. The validity of substituting $5 \%$ glycerol with $0.6 \mathrm{~mol} \mathrm{~L}^{-1} \mathrm{HCl}$ as a calibration medium was additionally proven through non-parametric tests: no significant differences were found by Mann-Whitney U-value and Kruskal-Wallis tests with respective $p$-values of 0.06876 and 0.0648 for $\mathrm{Zn}$, and 0.711 for $\mathrm{Cu}$. 
S. Luterotti et al.: Contribution to diagnostics/prognostics of tuberculosis in children. I. New methods of assaying zinc and simultaneously copper and zinc in diluted sera by flame atomic-absorption spectrometry, Acta Pharm. 65 (2015) 311-320.

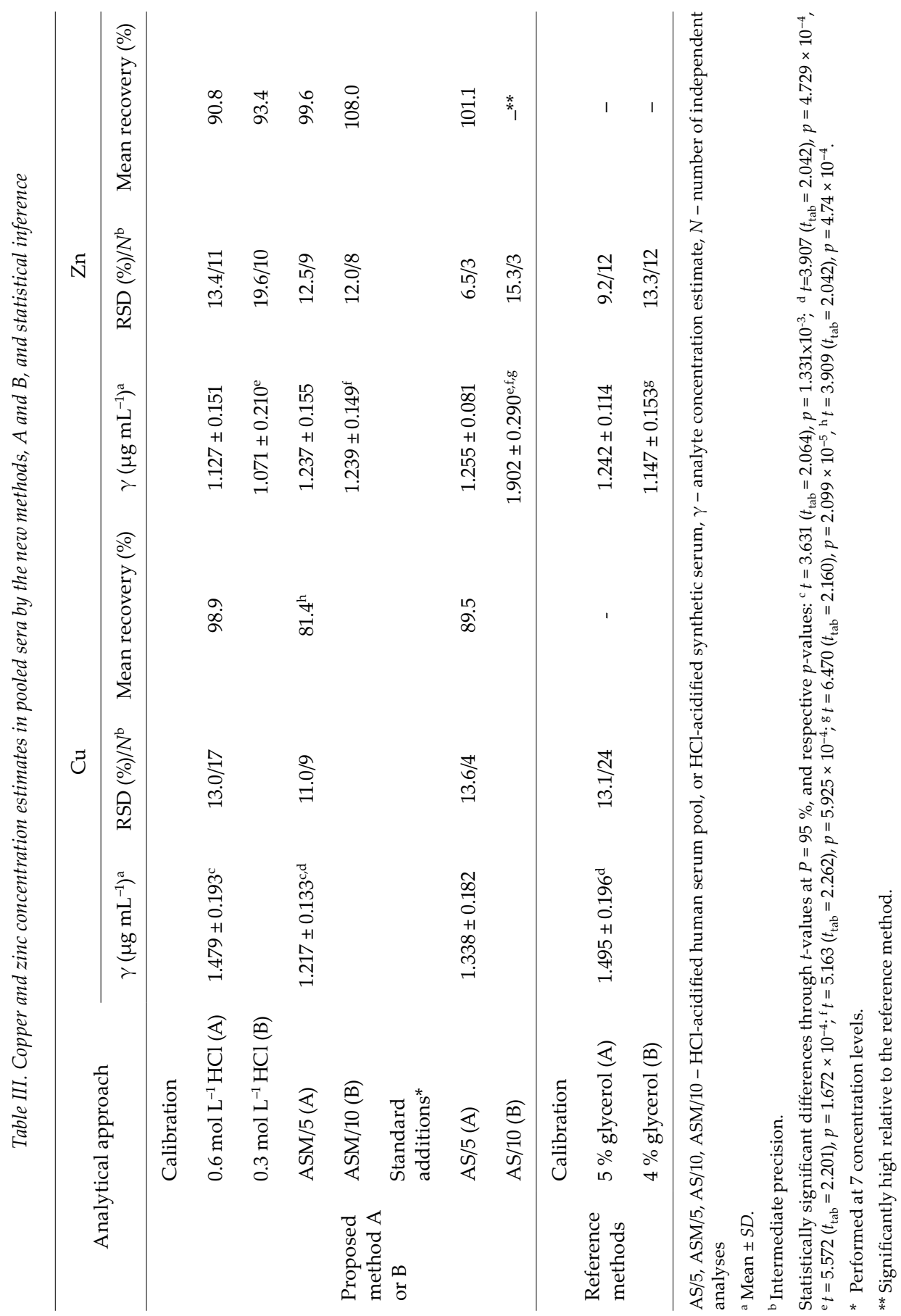


S. Luterotti et al:: Contribution to diagnostics/prognostics of tuberculosis in children. I. New methods of assaying zinc and simultaneously copper and zinc in diluted sera by flame atomic-absorption spectrometry, Acta Pharm. 65 (2015) 311-320.

Table IV. Precision of copper and zinc concentration estimates from the pooled sera by the new methods $A$ and $B$

\begin{tabular}{lcccc}
\hline & \multicolumn{2}{c}{$\mathrm{Cu}$} & \multicolumn{2}{c}{$\mathrm{Zn}$} \\
\cline { 2 - 5 } \multicolumn{1}{c}{$\begin{array}{c}\text { Analytical } \\
\text { approach }\end{array}$} & Repeatability & $\begin{array}{c}\text { Intermediate } \\
\text { precision }\end{array}$ & Repeatability & $\begin{array}{c}\text { Intermediate } \\
\text { precision }\end{array}$ \\
& $\mathrm{RSD}(\%) / n$ & $\mathrm{RSD}(\%) / N^{\mathrm{a}}$ & $\mathrm{RSD}(\%) / n$ & $\mathrm{RSD}(\%) / \mathrm{N}^{\mathrm{b}}$ \\
\hline $\begin{array}{l}\text { New methods } \\
\text { (calibration in HCl) }\end{array}$ & & & & \\
0.6 mol L L $^{-1}$ (A) & $0.0-9.8 / 2-6$ & $3.3-23.7 / 17$ & $1.3-21.1 / 2-3$ & $3.8 / 11$ \\
0.3 mol L $^{-1}$ (B) & & & $2.7-8.4 / 2-3$ & $11.4-24.6 / 10$ \\
$\begin{array}{l}\text { Reference methods } \\
\text { (calibration in glycerol) }\end{array}$ & & & & \\
$5 \%$ (A) & $0.0-6.1 / 3$ & $0.8-8.8 / 24$ & $1.6-4.2 / 3$ & $8.6-14.3 / 12$ \\
$4 \%$ (B) & & & $2.5-6.4 / 3-5$ & $6.1-22.8 / 12$ \\
\hline
\end{tabular}

$n$-number of independent analyses within-a-batch, $N$ - total number of independent analyses in different days Number of batches/days: ${ }^{\mathrm{a}} 5{ }^{\mathrm{b}} 4$.

Detection limit and precision. - Estimated $D L$ value for $\mathrm{Cu}$ was improved from 0.04 to $0.01 \mu \mathrm{g} \mathrm{mL} \mathrm{m}^{-1}$ when $5 \%$ glycerol was replaced with $0.6 \mathrm{~mol} \mathrm{~L}^{-1} \mathrm{HCl}$; for $\mathrm{Zn}, D L$ remained the same, $0.03 \mu \mathrm{g} \mathrm{mL}^{-1}$ (Table II).

Precision obtained by method A was comparable to that in $5 \%$ glycerol: for $\mathrm{Cu}$, it was $0-10 \%$ for repeatability and 3-24\% for intermediate precision compared to $0-6$ and $1-9 \%$, resp. (Table IV). For zinc, repeatability was 1-21 and intermediate precision $4 \%$ compared to $2-4$ and $9-14 \%$, resp., in $5 \%$ glycerol. Other approaches showed comparable precision values (Table III).

Method B. Method for zinc. - Table II shows that calibrations in the concentration range of 0.1 to $2.0 \mu \mathrm{g} \mathrm{mL}^{-1} \mathrm{Zn}$ in different media resulted in reliable calibration sensitivity (CS) (as evidenced by low $\mathrm{RSD}_{\mathrm{CS}}$ values). Good linearity fit was documented by the favourable coefficient of correlation of $R \geq 0.991$ with $p<1 \times 10^{-8}$ and by the low residual sum of squares in the range $10^{-2}$ to $10^{-3}$. CS values ranged from $0.24-0.25 \mathrm{~mL} \mathrm{\mu g}^{-1}$. Calibration recovery was 102-109 \%, close to that for zinc at the 5-fold dilution level (method A). In both the comparison of calibration sensitivity (Table II) and zinc concentration estimate in pooled sera (Table III), calibration in $4 \%$ glycerol significantly differed only from standard additions into $\mathrm{AS} / 10$ but not from calibrations in $\mathrm{ASM} / 10$ or $0.3 \mathrm{~mol} \mathrm{~L}{ }^{-1} \mathrm{HCl}$. Here again, the bias of zinc concentration estimate as high as $+8 \%$ was not recognized as significant.

Comparable precision of all approaches is evident (Tables III and IV).

Due to the high $D L$ evaluated for calibration in ASM/10 but acceptable $D L$ obtained in $0.3 \mathrm{~mol} \mathrm{~L}^{-1} \mathrm{HCl}$, the latter was chosen as medium to be applied throughout. Mann-Whitney U-value test and Kruskal-Wallis test served to additionally document the proper choice of $0.3 \mathrm{~mol} \mathrm{~L}^{-1} \mathrm{HCl}$ instead of $4 \%$ glycerol as a calibration medium: non-significant differences with respective $p$-values 0.22246 and 0.2103 were found. 
Zinc concentration found in the sera agrees well with the physiological values for general child population $(12,13)$.

No statistically significant differences were found between $\mathrm{Zn}$ concentration data obtained by method A (5-fold dilution) and method B (10-fold dilution). The latter method was characterized by slightly higher calibration sensitivity (by ca. $4 \%$ ), imprecision and $D L$ values but, what is important, by two-fold reduced consumption of sera samples.

\section{CONCLUSIONS}

The newly proposed method for simultaneous determination of copper and zinc by calibration in $0.6 \mathrm{~mol} \mathrm{~L}^{-1} \mathrm{HCl}$ (method $\left.\mathrm{A}\right)$ is simple and cheap, providing comparable analytical performance to that of the reference methods, but characterized by lower consumption of sera and reagents and higher analytical throughput. When analysis of zinc alone is the analytical task, new modification for assaying zinc (method B) is an option offering additional lowering of the consumption of sera samples, which is especially important when dealing with pediatric patients. Both methods, A and B, show comparable analytical figures of merit.

Considering also the favourable detection limiting values of $0.012 \mu \mathrm{g} \mathrm{mL}-1$ for $\mathrm{Cu}$ and 0.027 and $0.061 \mu \mathrm{g} \mathrm{mL}^{-1}$ for $\mathrm{Zn}$, the proposed methods seem to be applicable to routine work in clinical and diagnostic laboratories for analyzing sera of children with expected concentrations of $0.1-1.7 \mu \mathrm{g} \mathrm{mL}^{-1} \mathrm{Cu}$ and $0.6-1.4 \mu \mathrm{g} \mathrm{m}^{-1} \mathrm{Zn}(12,13)$.

\section{REFERENCES}

1. A. G. G. Dionisio, A. M. D. De Jesus, R. S. Amais, G. L. Donati, K. dos Anjos Miranda, B. B. Guerra, J. A. Nobrega and E. R. Pereira-Filho, Old and new flavors of flame (furnace) atomic absorption spectrometry, Int. J. Spectr. 2011, Article ID 262715 (1-30); DOI: 10.1155/2011/262715.

2. P. J. Parsons and F. Barbosa, Jr., Atomic spectrometry and trends in clinical laboratory medicine, Spectrochim. Acta Part B: At. Spectr. 62 (2007) 992-1003; DOI: 10.1016/j.sab.2007.03.007.

3. N. Weinstock and M. Uhlemann, Automated determination of copper in undiluted serum by atomic-absorption spectroscopy, Clin. Chem. 27 (1981) 1438-1440.

4. T. Makino and K. Takahara, Direct determination of plasma copper and zinc in infants by atomic absorption with discrete nebulization, Clin. Chem. 27 (1981) 1445-1447.

5. C. Terrés-Martos, M. Navarro-Alarcón, F. Martín-Lagos, H. L. G. de la Serrana and M. C. LópezMartínez, Determination of copper levels in serum of healthy subjects by atomic absorption spectrometry, Sci. Total Environ. 198 (1997) 97-103; DOI: 10.1016/S0048-9697(97)05448-X.

6. C. M. P. V. Lopes, A. A. Almeida, J. L. M. Santos and J. L. F. C. Lima, Automatic flow system for the sequential determination of copper in serum and urine by flame atomic absorption spectrometry, Anal. Chim. Acta 555 (2006) 370-376; DOI: 10.1016/j.aca.2005.09.013.

7. S. Salmela and E. Vuori, Improved direct determination of copper and zinc in a single serum dilution by atomic absorption spectrophotometry, At. Spectrosc. 5 (1984) 146-149.

8. Analytical Methods for Atomic Absorption Spectrometry, PerkinElmer ${ }^{\mathrm{TM}}$ Instruments, Perkin-Elmer Bodenseewerk, Überlingen, Germany, August 2000.

9. S. Luterotti and T. Vukman, Acidic method for determination of copper in blood serum by FAAS, Acta Pharm. 52 (2002) 143-148. 
10. S. Luterotti, T. Vukman Kordić and S. Dodig, Simultaneous determination of iron and copper in children's sera by FAAS, Acta Pharm. 61 (2011) 93-102; DOI: 10.2478/v10007-011-008-4.

11. International Conference on Harmonisation of Technical Requirements for Registration of Pharmaceuticals for Human Use, ICH Harmonized Tripartite Guideline. Validation of Analytical Procedures: Text and Methodology Q2(R1), Current Step 4 version, ICH, London 2005.

12. Z. Flegar-Meštrić, N. Jagarinec, B. Šurina, D. Vrhovski-Hebrang, V. Preden-Kereković, S. Perkov and B. Smud-Makalouš, Reference intervals for biochemistry analytes determined in the sera of children and adolescents from Zagreb, Croatia, Biochem. Med. 6 (1996) 277-288.

13. G. Lockitch, A. C. Halstead, L. Wadsworth, G. Quigley, L. Reston and B. Jacobson, Age- and sexspecific pediatric reference intervals and correlations for zinc, copper, selenium, iron, vitamins A and E, and related proteins, Clin. Chem. 34 (1988) 1625-1628.

14. A. Gustavo González and M. Ángeles Herrador, A practical guide to analytical method validation, including measurement uncertainty and accuracy profiles, Trends Anal. Chem. 26 (2007) 227-237; DOI: 10.1016/j.trac.2007.01.009. 